\title{
THE REGENERATION OF THE TAIL IN LUMBRICULUS.
}

\author{
HARRIET RANDOLPH.
}

\section{CONTENTS.}

Part I.

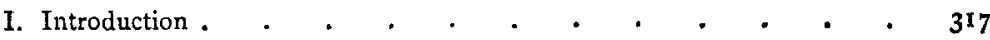

Part II.

II. General history of division . . . . . . . . . 321

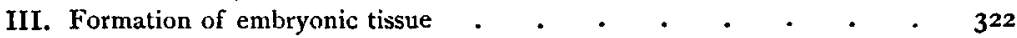

I. Ectoderm and entoderm $. \quad . \quad . \quad . \quad . \quad . \quad+322$

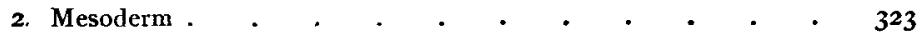

IV. Differentiation of regenerated tissue . . . . . . . . 326

I. Ectoderm . . . . . . . . . . . 326

2. Mesoderm • . . . . . . . . . . 327

PART III.

V. Regeneration and agamic reproduction . . . . . . . $\quad$. 329

VI. Relation of the observations of regeneration in Lumbriculus to the germ-layer theory . . . . . . . . . . 33I

VII. Peritoneum and neoblasts.$\quad \cdot \quad \cdot \quad \cdot \quad \cdot \quad \cdot \quad \cdot \quad \cdot 333$

\section{PART I.}

\section{INTRODUCTION.}

THE following paper is offered as a contribution to our knowledge of the regeneration of lost parts, and contains more especially the results of an attempt to discover the precise origin of the histological elements.

Although the regeneration of lost parts has long been known, ${ }^{1}$ in so far as its broader features are concerned, it is only within

1 For an extended account of the early observers and their work, see MilneEdwards (15) and Fraisse (7), where the bibliography of the subject can be found. 
a comparatively recent time that any attempt has been made to determine the origin of the regenerated tissues and the relation of their cells to those of the old tissues.

Histological details have been studied by Fraisse (7) for Reptilia and Amphibia, by Bülow (3) in Lumbriculus, and by Dendy (5) in Antedon.

In regard to the origin of the new tissues, Fraisse gives the following summary of his observations :-

"Somit können wir im Grossen und Ganzen constatiren, dass eine Gewebeform nur im Stande ist bei der Regeneration wiederum dasselbe Gewebe zu erzeugen, oder, wenn wir die verschiedenartigen Gewebe der Bindesubstanzen mit in Betracht ziehen, Gewebe zu erzeugen welche ursprünglich aus demselben Keimblatt ihren Ursprung genommen haben."

In the regeneration of the visceral mass of Antedon rosaceus, the new entoderm is said to arise from the ectoderm around the edges of the wound.

Bülow's investigation of the regeneration of Lumbriculus led him to conclusions that, like those of Dendy for Antedon, show a lack of homology between the embryonic and the regenerated tissues. His summary of his results is as follows :-

"Die drei wohl unterscheidbaren Schichten im normalen wachsenden Afterende der Anneliden, die caudalen oder Schwanzkeimschichten sind den embryonalen Keimblättern dynamisch gleichwerthig, da sie dieselben Organe bilden wie diese. Nur in der Entstehung der Mesodermschicht als des ersten Differenzirungsproduktes der primären zwei Schichten ist eine Modification eingetreten: sie nimmt nicht wie im Embryo aus dem Entoderm ihren Ursprung, sondern aus derjenigen Stelle wo äussere und innere caudale Keimschicht in einander übergehen."

Transverse sections of the newly formed end of the regenerated tail show a two-layered arrangement with a dorsal depression, which Bülow considered a recurrence of the gastrula stage. From the points corresponding to the lips of the blastopore he derives the new mesoderm :-

“I. Das Mesoderm entsteht durch Einwucherung von Zellen, welche aus der Uebergangsstelle von Ekto- und Entoderm ihren Ursprung nehmen."

But the resemblance in section to the form of the gastrula 
in optical section, as has already been pointed out by Kleinenberg ( 11 ), is the result of the invagination of the new proctodeum, and of the fact that the anal opening is situated at first somewhat dorsally. If, therefore, the new mesoderm arises from this point, it is ectodermic in origin; but in my view it is to be considered as arising from elements in the old mesoderm.

Other important results reached by Bülow are as follows :-

“3. Der centrale Theil des Bauchnervensystems, dessgleichen die Spinalganglien entstehen aus einer paarigen Ektodermanlage; es kommen zu dem nervösen Theil des Bauchnervenstranges von Lumbriculus keine mesodermalen Elemente hinzu, wie Semper dies für die Naiden angiebt."

With this my results are in perfect agreement.

“ 5. Die Chordazellen Semper's sind Abkömmlinge des mittleren Keimblattes; sie verschwinden dort wo die Anlage des "Neurochords' beginnt."

My observations confirm the first part of this statement, but show that the so-called Chorda cells persist in every segment except the most anterior of the adult worm. For these cells I have proposed in a preliminary paper (16) the name Neoblasts.

"6. Die Muskelplatten und die sonstigen muskulösen Elemente sind mesodermalen Ursprungs, dessgleichen Segmentalorgane, 'Leberzellen' und Blutgefasssystem."

In regard to the nephridia, I do not find that the mesoderm alone takes part in their formation, although I am unable to decide exactly how much arises from the ectoderm. The material seems to me unfavorable for a determination of the question; and as among a number of forms examined Lumbriculus gives the clearest picture of regeneration, the matter must probably be decided by analogy from the embryology of this or of an allied form. All the processes of development are less distinct in the regenerated tail than in the embryo, in consequence of the reduced size of the cells and the relatively smaller space that they occupy. It is then perhaps not remarkable that some details of the development of the regenerated tissue cannot be elucidated.

On account of the more normal aspect of its tissues Lumbriculus is more suitable for a study of the phenomena of regeneration than any other form that I have examined. My first investigation of this subject was made upon Lumbricus; but 
long and careful work upon all stages of development gave no clue to the solution of the problem, and it was only after the discovery of the process in Lumbriculus that I could trace in Lumbricus an apparent agreement. Since that time I have also carefully examined the mode of regeneration in Tubifex and the budding of Nais elinguis and Chrotogaster. It is absolutely necessary, in order to gain a thorough insight into the growth of any of these forms, to study specimens of many stages. Although in regeneration there is a progressive development, and the new mesoderm of the anal segment retains its embryonic condition to a certain extent for a considerable time, its most striking stages are passed through during the first and second days (neoblasts and circular muscles). By the time that the anterior region of the new tail is differentiated, the most posterior part has long passed through its initial phases. This seems the more worthy of remark, since it is probable that one cause contributing to the misconception of Bülow, as to the origin of the new mesoderm, was the attempt to trace the whole process in the same series of sections.

I gladly avail myself of this opportunity to acknowledge my great indebtedness to Professor E. B. Wilson, under whose direction in the biological laboratory of Bryn Mawr College this work was carried on nearly to completion. It was finished in the zoological laboratory of the University of Zürich, and for the interest that Professor Lang has shown in my work I am very grateful.

Methods. - The methods that were found to give the most satisfaction were:-

For Preserving and Hardening. - Perenyi's fluid, one to two hours ; alcohol, 70 per cent, one hour, followed by 90 per cent.

For Staining. - Borax carmine, acid alcohol a few minutes subsequently neutralized by very weak ammoniacal alcohol, and Kleinenberg's hæmatoxylin.

For the Study of the Development of the Muscles. - Borax carmine, followed after the sections were fastened to the slide by picric acid dissolved in 70 per cent alcohol.

Corrosive sublimate and chrom-acetic acid were used without as great success, and no single staining gave such clear and definite results as the double staining described. 
In making preparations for the examination of the peritoneum from its inner surface, the clearest views were obtained by staining with borax carmine and transferring to glycerine, at first dilute and, finally, of nearly full strength. After a few days the worms can be opened along any line desired, the alimentary canal, etc., removed, and the body-wall opened out flat and mounted in glycerine. Silver nitrate was used, but from the extreme sensitiveness of Lumbriculus it was impossible to stupefy the worms by the usual methods without their falling to pieces, and silver nitrate upon preserved tissue, or from the outside, did not yield entirely good results.

In the case of Lumbricus, where the presence of earth in the alimentary canal rendered it difficult, if not impossible, to get an unbroken series of sections, the difficulty was obviated by keeping the worms for several days in decayed stump earth (humus), or in white or brown bread. The worms can easily penetrate slices of bread moistened with water, and if the bread is changed every day, no injurious fermentation occurs. These two media were thought to offer less chance for pathological change than the less nourishing diet of filter paper, which answers to some extent for worms that are to be used almost at once, and where there is no especial demand upon the system, as is the case in regeneration.

\section{PART II. DESCRIPTIVE.}

The Lumbriculidæ, as is well known, possess in a remarkable degree the power to divide spontaneously and to reproduce the extremity cast off or lost. In this respect they agree with the Naids and some marine Annelids, but the regenerative process of the latter forms differs in that zones of new tissue are developed before separation.

After artificial division the regeneration in Lumbriculus seems to be entirely normal.

II. The General History of Division, whether artificial or brought about by the worm itself, is as follows : Immediately upon the separation of the worm into two parts, or perhaps before the separation and consequent upon the stimulus that causes it, a strong contraction of the muscles takes place. In 
cases of normal division I think the separation is probably brought about by violent muscular contraction. Such division sometimes takes place while the worm is executing its characteristic snake-like swimming movements, and under these circumstances it appears to suddenly fall apart.

The contraction is most marked in the longitudinal muscles, and the effect is to draw over at their free ends the other layers of the body-wall and of the wall of the alimentary canal to which they are attached. The outer wall is curved inward, and the wall of the intestine outward, so as to almost or quite shut in the cœlomic cavity of the end somite. The flow of blood from the broken ends of the vessels is very quickly checked, a result possibly of the great contraction which may be imagined to extend also to the walls of the blood vessels.

The processes of growth begin very soon, and in many cases the new tissue is sufficiently developed to be seen after the lapse of a few hours.

\section{The Formation of Embryonic Tissue.}

By the contraction of the muscles, the posterior edges of the walls of the cœlomic cavity of the last somite are brought close together, the ectoderm approaching the entoderm.

\section{Ectoderm and Entoderm.}

The next step in development seems to be simple proliferation of the ectoderm and entoderm, although in what way the new tissue arises I am unable to state. A union of the new ectoderm and entoderm is very soon established, and at the same time a rapid increase in length takes place. ${ }^{1}$

1 In the regeneration of the tail in Lumbricus, where the process is a very slow one, the union of ectoderm and entoderm takes place only after a considerable growth of each separately. After a period of growth posteriorly, the new ectoderm begins to invaginate to form the proctodeum. It grows in from the side, as is the case also in Lumbriculus, and for a considerable time ends blindly, sometimes dividing into two or more branches, which extend obliquely in different directions. It seems as if union were established between the new entoderm and that branch of the proctodeum with which it first comes into contact. In consequence of this mode of growth, transverse sections of early stages sometimes show the proctodeum and the new entodermic tube cut at a different level, the two having passed each other without coming together. 
The new ectoderm is composed of thin extended cells, undifferentiated in structure and staining faintly.

From the entoderm arise cells that are almost indistinguishable from those of the old tissue.

\section{Mesoderm.}

It has been noticed by other observers that in transverse sections of the growing tail of Lumbriculus large cells with large nuclei and with nucleoli that stain deeply are to be seen near the ventral nerve cord. They are perhaps most widely known through the study by Semper (23) of the budding of the Naids and Chætogaster. After describing the paired origin of the mesodermal plate from the ventral ectoderm on each side of the middle line (p. I69), the author continues: "Im darauf folgenden [Schnitte] theilt sich die symmetrische Mesodermplatte - die wir bis dahin vielleicht als Axenstrang bezeichnen könnten - in zwei isolirte Hälften, indem sich genau in der Mittellinie 2-4 mit eigenthümlichen starkglänzenden Kernkörperchen versehene Zellen scharf absondern. Diese Zellen lassen sich ganz regelmässig durch alle darauf folgenden Schnitte hindurch verfolgen; sie behalten immer ihr eigenthümliches Aussehen und sie bezeichnen eine Axe in den neu angelegten Segmenten des Thieres, welche zu den aus dem Mesoderm und Ectoderm allmälig sich abgliedernden Theilen genau in derselben morphologischen Lagerungsbeziehung steht, wie die chorda dorsalis der Embryonen der Wirbelthiere und der Ascidien."

After describing the relatively similar arrangement of organs around this axis in Annelids, Semper names it the chorda, "denn sie spielt... in dem auswachsenden Hinterende einer Nais genau dieselbe Rolle wie die echte chorda der Vertebraten."

I quote entire Semper's brief summary of his results, because of the close connection of every paragraph with the subject of this paper. They are as follows :-

" I. Es bildet sich eben vor dem After auf der neuralen Seite durch Wucherung aus dem ursprünglich einfachen Ectoderm eine Axenplatte;

“2. diese Axenplatte zerfällt dann in zwei Mesodermplatten, welche von einem axialen Zellstrang getrennt werden, der, über dem Darme liegend, der Chorda der Wirbelthiere zu vergleichen ist; 
[VOL. VII.

" 3 . dieser Chordazellenstrang ist continuirlich durch alle Schnitte hindurch $\mathrm{zu}$ verfolgen, welche noch embryonalen Charakter tragen, und er liegt hart unter den beiden Nervensträngen des centralen Nervensystems ;

"4. die Muskelblätter wachsen gleichzeitig von zwei der Axe des Körpers entsprechenden Linien aus neural- und cardialwärts, genau wie bei Wirbelthieren; es wird somit

" 5. durch diese Vorgänge eine Axe auch in Anneliden bezeichnet von welcher nach unten hin sich das animale, nach oben hin das vegetative Rohr schliesst.

"Es ist endlich

“6. sehr wahrscheinlich — obgleich ich es bis jetzt nicht völlig ausser Zweifel stellen konnte - dass das gesammte Mesoderm mit Einschluss der Darmfaserplatte aus dem Ectoderm herstammt."

Thus the chorda cells are to be considered as arising together with the rest of the mesoderm from the ectoderm.

Builow notices the presence of the chorda cells, but gives no other explanation of their meaning.

In my view, however, it is from these large cells that the greater part of the mesoderm is regenerated, and they do not arise from the ectoderm but are present in the mesoderm of the adult individual. On closer examination they are found to be limited to a definite tract of the peritoneum and to extend throughout the greater part if not the entire extent of the worm. Their position and aspect are shown in Fig. I. They lie along the free surface of the ventral longitudinal muscles, on each side of the ventral nerve cord, between it and the ventral setæ. The nuclei are round or oval in section, granular, and possessing large and deeply staining nucleoli; they are surrounded by cell bodies of irregular form, which stain more deeply than the adjacent protoplasm. These large cells, for which I have proposed the name neoblasts, are distinguishable from the remaining cells of the peritoneum by their great size and by the presence of a cell body, which I have not been able to discover in the case of the ordinary peritoneal cells. The neoblasts are to be found in every somite (Fig. 2), with the exception of perhaps one or more at the anterior extremity; and, on the separation of the worm into parts, the one or more present in the end somite soon begins to divide. I have traced the 
presence and the position of the neoblasts in preparations made by opening the worm so that the inner surface of the body-wall could be examined (Fig. 2), and have also found them regularly recurring in series of transverse sections, in alternation with the successive setæ.

About the end of the first day the ventral space within the proliferated ectoderm is occupied by several large cells lying free and in process of division (Figs. 3 and 4). At first the products of division are conspicuously large. In consequence of the great size of the neoblasts their division, especially at first, takes place very slowly. To this, I think, is due the fact that one or more are so generally found in some phase of cell division. The reverse is, perhaps, true for the cells of ectoderm and entoderm, although here the much smaller size doubtless adds greatly to the difficulty of distinguishing the stages of division.

At a somewhat later period the new cells thus formed are smaller, and only a few neoblasts are to be found scattered among the otherwise uniform tissue. The cells that arise in this way eventually occupy the greater part of the ventral and lateral space between the ectoderm and entoderm, reaching dorsally on each side the level of the dorsal setæ (Fig. 8, x).

In very early stages, as soon as the ectoderm and entoderm have extended themselves sufficiently to form a new cavity, there are present - dorsally, laterally, and ventrally - small cells that seem to be wholly unconnected with the neoblasts and their products (Figs. 3, 5, 6). They are much smaller, and appear in the earlier stages when the neoblasts are few in number and before their division products have become in any way differentiated. Of the source of these cells I am not entirely sure. One very clear set of early sections, however, shows with great distinctness cell division taking place in the region of the dorsal peritoneum just at the posterior limit of the old tissue (Fig. 5, p). Upon careful examination I do not find any connection between these small mesodermic cells and the ectoderm and entoderm. I infer, therefore, that the regeneration of the dorsal mesoderm is similar to that of the ventral, but I believe that the tissue in the two regions arises separately. 


\section{Differentiation of Regenerated Tissue.}

\section{Ectoderm.}

At an early stage the ectoderm begins to increase in thickness in the ventral and lateral regions. The nuclei arrange themselves in a very definite way into a number of groups, five on each side of the median line. Of these the two ventral cell masses are the first to appear, and they are the foundations of the future ventral nerve cord. The layers of cells arrange themselves into two groups each approximately hemispherical in section and which are in contact at the inner surface of the ectoderm (Fig. 8). The two foundations gradually unite and nerve fibres appear near the inner surface in small bundles, which subsequently grow larger (Fig. 10). The developing nerve cord gradually leaves the ectoderm from which it arose, but retains in its form traces of its paired origin. A thin layer of mesodermic tissue (circular muscles) eventually insinuates itself between the ventral nerve cord and the ectoderm which lies beneatḥ (Figs. 9, I0, I1, 12, 13).

The fifth ectodermic foundation on each side gives rise to the dorsal setæ. From the fourth foundation arises the lateral nerve line whose cells lie free in the body cavity, but by means of fibres retain their connection with the ectoderm.

The second and third foundations on each side (Fig. 8) are evidently connected with the development of the nephridia and the ventral setigerous glands, but to just what extent I am unable to discover (Fig. I4). In the introductory part I have already alluded to the small size of the cells and the contracted space as productive of greater obscurity than is to be found in similar stages of developing embryos of related forms. It seems to me, however, not improbable that a form may be found that will show clearly in its development the extent to which the second cell row takes part in the formation of the nephridia. If the part ${ }^{1}$ that Meyer assigns to the "primary mesoderm" proves to be general for all Annelids, the nephridia will then be found to be composed of three kinds of tissue. In this work I am not aware of anything for or against this special point.

\footnotetext{
I See under Differentiation of Mesoderm.
} 


\section{Mesoderm.}

I. The small cells that I have described as arising apart from the neoblasts, and as present at a very early stage, are the first of the mesodermic elements to become differentiated, and from them are developed the circular muscles. They are to be found - ventrally, laterally, and dorsally - close to the newly formed ectoderm, but in greatest number in the ventral region, where they are arranged with some degree of regularity in one or more longitudinal rows on each side of the median line. The cells are at first free in the body cavity, later the cell body becomes flattened against the base line of the ectoderm and the nucleus stands out into the body cavity. The next step in the development is the appearance in the cell body of exceedingly faint striations in a direction at right angles to the longitudinal axis of the worm (Fig. 17). At first the protoplasm of the cell extends only a little way on each side of the nucleus. In this stage one sagittal section may show a number of nuclei and the striated protoplasm of their cells, and the next, in corresponding places, only a row of protoplasmic dots, which are the pointed ends of the cells. The striations become more distinct and are seen to be the lines of separation of the protoplasm into fibrilla. The cells grow in length around the inside of the ectoderm, becoming many times as long as their width. The structure of the muscle cell is shown in Figs. 18, 19. In order to see the first stage of the formation of the fibrillæ, it is necessary to examine specimens of about one day's growth.

In this way the circular muscles arise around the inner surface of the ectoderm. This mesoderm seems to be the only tissue of its kind that penetrates the dorsal region. Here it forms a loose tissue surrounding two spaces that are the foundation of the dorsal vessel (Fig. I5). These lie at first far apart, but gradually move together to the median line and fuse.

The origin of the circular muscles, in this case, is in sharp contrast to that described by Bergh (2) for the corresponding structures in the embryology of Lumbricus. At a later stage the lateral cell rows to which Bergh ascribes their origin are present in the ectoderm of Lumbriculus, as in Lumbricus, but at this time the circular muscles have long been formed (Figs. I 3, 20). 
The mesoderm just described seems to resemble the "migratory mesoblast " of Wilson (25), and the "primary mesoderm" of Meyer (14). This tissue is described by both observers as arising in the embryo from a common foundation, but according to Meyer it is distinct in origin from the great mass of the mesoderm. It is true mesoderm, while the latter is transformed reproductive tissue. From the "primary mesoderm" Meyer derives the circular and the transverse muscles, the muscles of setæ, dissepiments, and mesenteries, as well as the retroperitoneal connective tissue, and in some cases part of the nephridia.

In the regenerated tail of Lumbriculus these small cells give rise to the circular muscles and to the wall of the dorsal bloodvessel and its connections, and they arise separately from the great mass of the mesoderm. The ventral mesentery, however, as will be shown in the following description, appears to arise solely from the neoblasts.

2. The continued division of the neoblasts results in a compact mass of embryonic cells that fill all the ventral space (Fig. 6). A little later this solid mass extends dorsally on each side to the height of the dorsal setæ (Fig. 8, x). A separation in the new mesodermic tissue now takes place in the median dorsoventral line, and also at a little distance from it on each side, giving rise to four groups of cells, a small pair on each side of the median line and one larger mass on each side of these. Very soon after this stage the smaller middle groups fuse, and thus three cell masses are formed, two lateral and a composite median mass (Figs. 6 and 7). Cavities soon appear, one in each lateral mass and two in the median, corresponding to the two masses that formed it. These two median cavities ultimately coalesce and become the part of the coelom between the ventral nerve cord and the ventral blood-vessel (Figs. 10 and II).

The differentiation of the mesoderm follows rapidly upon its development. Each lateral element separates into the parietal and visceral layer of its side. By continued cell division the parietal layer remains of considerable thickness; but the visceral layer becomes gradually more and more extended in consequence of the increase of the worm in length. From the parietal layer are developed the longitudinal muscles in their well-known dis- 
tribution. They begin to develop at an appreciable time after the circular muscles are formed.

In the meantime the cavity in the centre of the median mesodermal element has grown larger, and the cells have arranged themselves around it as a wall. The dorsal part of this wall now bends down ventrally, forming a groove. The sides of the groove close in above, and it becomes a tube, which hangs suspended in the cavity of the former median element. This tube is the ventral blood-vessel. The part of the wall that does not take part in the formation of the ventral blood-vessel forms the ventral mesentery by which the blood-vessel is suspended (Fig. II).

PART III. GENERAL.

\section{Regeneration and Agamic Reproduction.}

The general aspects of the preceding work are to be sought in the relation of regeneration to agamic reproduction and to the homology of the germ layers.

The first subject has been most fully treated by von Kennel (Io) and Lang (13).

In a comprehensive survey of the whole question they arrived at conclusions to which I have been led by the study of histological details in a more limited field. In general they consider the capacity for regeneration, which is found so widely distributed in the animal kingdom, to be the starting-point for the more special case of budding.

From my observations on the Oligochæta the two processes seem to be connected on definite structural grounds, as shown by the following series of forms in the order in which they stand :-

Lumbricus, Tubifex, Lumbriculus, Nais.

In Lumbricus the process is slowest, the non-differentiated cells appear to be all alike, and the elements of old and of new tissue are confused beyond distinction until one has found the key elsewhere.

Tubifex shows a great advance upon this condition, and perhaps the greatest gap in the series is to be found here. In Tubifex the presence of neoblasts shows a well-marked adapta- 
tion for regeneration. The reaction of the organism, however, is not rapid ; the blood-vessels close less quickly or less completely than in Lumbriculus, causing coagulation in the growing end and giving to the whole worm a pale appearance.

In Lumbriculus this process is accomplished quickly, and preparations made twenty-four hours after the section of the worm have an almost diagrammatic clearness. It is possible that the rapidity of the growth in Lumbriculus may be the direct result of the prevention of the waste from the broken ends of the blood-vessels. The great size of the neoblasts is doubtless in direct relation to the rapid regeneration in this form.

The development of the budding zones in Nais elinguis is characterized by remarkable rapidity. The great increase of tissue becomes quickly an accomplished fact, instead of exhibiting a progressive development such as takes place in ordinary growth. It is probably of great advantage to the worm to have the period during which the middle region of its body is occupied by an inert mass as much shortened as is possible. This probably causes simultaneous development and, together with the rapid accumulation of new tissue under pressure at both ends of the growing zone, tends to obliterate the steps by which the process is brought about.

In Chætogaster the development is even more rapid and more compressed than in Nais.

The formation of budding zones is begun, as is well known, by the multiplication of peritoneal cells, which correspond to the neoblasts of Lumbriculus.

The largest neoblasts of the series are those of Lumbriculus, and those of Tubifex are second in size. I have not seen any evidence of division of the neoblasts in these two forms until after the division of the worm. It is probable that there is a tendency in the direction of storing up as much material as possible in each neoblast in preparation for the great and sudden demand for regeneration. In those forms in which agamic reproduction has become established, there is a preliminary or introductory stage of multiplication of undifferentiated cells, which therefore do not need to attain to so great a size. With the increase of the tendency to accumulation beyond the size limit of the neoblast, the conditions for cell division would exist, and with cell division the process of budding is essentially begun. 
It has been suggested to me that a parallel exists between the neoblasts and the "islands" of undifferentiated or embryonic tissue in the larval stages of insects described by van Rees (17): Regions of embryonic cells remain undifferentiated until the close of the larval stage, and then begin their development to form the tissues of the imago. In the same way we find in Annelids a store of reserve material arranged in a very definite manner in response to a special need.

VI. The Relation of the Observations on the Regeneration of Lumbriculus to THE Germ LAyer Theory.

Without entering into an elaborate discussion of the germ layers, I may point out the fact that the observations on agamic reproduction and regeneration have been cited by a number of writers as subversive of the homology of the layers.

To give a few instances: Seeliger (19) asserts that among Ascidians the embryological development is not repeated in all its details in the development from the bud. In the bud the wall of the peribranchial space is entodermic in origin, while in the development from the egg it arises from the ectoderm.

In the buds of Salpa and of Pyrosoma (20) the nervous system and the wall of the peribranchial space are developed from the mesoderm, while in the embryo they are ectodermic.

The observations of Seeliger upon the Ascidians show that the mesoblast and chorda of this group have a different origin from that of Amphioxus, and that they are therefore not homologous.

According to the same author the budding of the Tunicates is not to be harmonized with that of the Bryozoa. Hatschek (8) in 1879 thought that all the germ layers take part in the formation of the bud in Pedicellina. Seeliger, however, has pointed out (2I) that ectoderm and mesoderm together give rise to all the organs of the adult, there being a common ectodermic foundation for the atrium, alimentary canal, and ganglion. In a later paper (22) he finds a similar mode of formation of the bud in the Gymnolæmata. More recently the observations of Davenport on Paludicella (4) lead to the conclusion that the two layers of which the bud consists are respectively mesoderm 
and indifferent tissue, which is later differentiated into ectoderm and entoderm.

Von Kennel argues (9) that while the homology of the germ layers of Vertebrates is established beyond doubt, among Invertebrates it does not hold. This conclusion is based upon the observation that in Ctenodrilus a considerable part of the posterior region of the alimentary canal is proctodeum; and that, therefore, when a new zooid is formed in this region of the worm, the lining of its alimentary tract is ectodermic in origin, and hence cannot be homologized with the entodermic canal of the individual produced from the egg.

Semper (23) in the budding of the Naids and Chatogaster derived the mesoderm of the bud from ectodermic cells. ${ }^{1}$

In the case of Antedon referred to in the introduction, it seems possible that some of the entodermic tissue may remain after the ejection of the visceral mass. If only a very small part remains, the regeneration of the visceral mass is not an unparalleled case.

Lastly, Bülow's results were opposed to the theory of the homology of the germ layers.

My results, however, are in sharp contrast to those of Bülow in regard to the origin of the new mesoderm. My observations show that each germ layer gives rise to the corresponding new tissue in the regenerated part, - or, in other words, that the structures of the newly formed somites may be traced to the ectoderm, mesoderm, and entoderm, respectively, of the developed part of the worm, just as these arose from the respective germ layers of the embryo.

The method of regeneration in Lumbriculus seems to be in harmony with the proposition stated by Balfour (I) in regard to the mesoblast, that with its differentiation as a distinct layer the two primary layers lost for the most part the capacity they primitively possessed of giving rise to structures now developing from the mesoblast.

On the other hand, the existence of a third germ layer is not admitted by some investigators. In this connection Kleinen-

\footnotetext{
1 The presence of neoblasts in these forms has already been alluded to. The large contributions from the ectoderm are probably to be regarded as the condensation of the lateral foundations that arise in the ectoderm and subsequently come to lie more centrally.
} 
berg says that a rational classification of tissues can be made only from a physiological standpoint. "Alle embryologischen Erscheinungen laufen in - meist sehr weit zurückliegendephysiologische Zustände aus. So wie die Sachen liegen, verstehe ich nicht, auf welche Weise die zahlreichen und heterogenen Organe, welche konventionell vom mittleren Keimblatt abgeleitet wcrden, aus einer einheitlichen indifferenten Anlage entstehen konnten."

It is doubtless in harmony with the view that there is no middle germ layer to consider that the tissues commonly termed mesoderm have collectively no worth independently of the two primary germ layers. Although from this point of view the segregation of mesoblast into the primary mesoblasts may be regarded as analogous to the segregation of the material of the central nervous system into neuroblasts, yet the difference in the regeneration of the nervous system and of the mesoderm the recurrence to the three-layered condition of the embryoseems to me to indicate a marked difference in the rank of the two tissues.

\section{ViI. Peritoneum and Neoblasts.}

It seems probable that the peritoneum, as the least differentiated of the mesoblastic tissues and in some of the Annelids very little changed from the embryonic condition, contains the mesoblastic elements. This is in harmony with the theory of Weismann (24) that the complexity of protoplasm is in proportion to its non-differentiation.

This view of the condition of the peritoneum is the one most generally accepted. Von Kennel says it is in Ctenodrilus "als undifferenzirtes Mesodermgewebe zu betrachten"; and Rohde (18), for the Limicolæ in general, "Dieses Gewebe ist in engsten Zusammenhang mit der Bildung der Muskulatur zu bringen," and "ist als Bildungsgewebe der Muskeln zu betrachten."

The other view is that of Kleinenberg, who considers the peritoneum of Lopadorhynchus to be transformed muscle tissue and hence a tertiary structure, as the muscles are a secondary formation from the ectoderm.

Bülow does not give the details of the formation of the muscles in the regeneration of Lumbriculus and makes no 
mention of the peritoneum. He refers to large cells that appear occasionally in a series of cross-sections with the comment that they are probably the "chorda cells" of Semper.

The neoblasts must in my view be regarded as specialized embryonic cells set apart for the formation of new mesodermic tissue immediately after the fission of the worm. Since they are closely connected in origin with the peritoneal tissue, they are probably to be regarded as belonging to it.

Kükenthal (I2) figures cells in Tubifex very like the neoblasts, lying among the muscles as seen in tangential section. This corresponds to the position of the neoblasts, since, from the curvature of the body-wall and also from the varying degree of contraction of the muscles, in sections in certain planes the cells are apparently embedded in tissue. Kükenthal gives these as one source of the lymphoid cells of Tubifex. Since, however, he expressly states that he has never seen these granulated cells either enter or leave the muscles, and that the lymphoid cells have a different structure, it occurs to me as possible that what he has seen are really the neoblasts.

In different forms of Annelids described by Eisig (6), Kükenthal, and others, the peritoneum gives rise to ova and to lymphoid cells. In the Phylactolamata the eggs arise from the cœlomic epithelium of the budding region (4). In Pyrosoma also, according to the researches of Seeliger (20), the mesoderm of the budding region gives rise to eggs.

It has been suggested to me by Professor E. B. Wilson that the neoblasts are comparable to ova. That unlike ova they give rise only to mesoderm seems to me not out of harmony with this conception, since the elements of the two other germ layers may be suppressed from lack of need or of opportunity to develop. They may represent the ova of the primitive worm which were originally produced in every somite, but which have ceased to develop in any except a few of the segments of the anterior region of the body. In this connection the recent paper of Meyer (I4) on the derivation of the Annelids is of great interest. If almost the whole Annelidan mesoderm is reproductive tissue, the explanation of the regenerative power of peritoneal tissue is simplified to the last degree. In any case there is a close connection in the development in general between ova and peritoneal cells. 
In the Tunicates there seems to be an intimate relation between ova and undifferentiated mesoderm. According to the researches of Seeliger (20) the reproductive organs of an individual and the undifferentiated mesoderm of its buds arise from a common foundation. Thus is explained the great part taken by this mesoderm in the formation of organs that developed in the embryo from another layer. "Denn als einem Theil des ursprünglichen Geschlechtsapparates muss seinen Zellen die Fähigkeit innewohnen, einen vollständigen Organismus und somit auch alle Gewebe aus sich hervorgehen zu lassen. Bei Pyrosomen und Salpen äussert sich diese Fähigkeit . . . in der Bildung des Nervensystems, des Herzens, der Peribranchialwände, der Muskulatur, des Bindegewebes und des Eläoblastes."

ZüRICH, February, I892.

\section{LIST OF PAPERS REFERRED TO.}

I. Balfour, F. M. Comparative Embryology. 1885 .

2. BERGH, R. S. Neue Beiträge zur Embryologie der Anneliden. Zeitschr. f. wiss. Zooi., Bd. L. I8go.

3. BüLow, C. Die Keimschichten des wachsenden Schwanzendes von Lumbriculus variegatus. Zeitschr.f. wiss. Zool., Bd. XXXIX. 1883.

4. Davenport, C. B. Observations on Budding in Paludicella and Some Other Bryozoa. Bull. Mus. Comp. Zool., Vol. XXII, No. I. I89r.

5. Dendy, A. On the Regeneration of the Visceral Mass in Antedon rosaceus. Studies from the Biological Laboratories of the Owens College, Vol. I. Manchester, 1886.

6. Eisig, H. Monographie der Capitelliden. Fauna u. Flora d. Golfes zon Neapel, XVI Monographie. 1887.

7. Fraisse, P. Die Regeneration von Gewebe und Organen bei den Wirbelthieren. Cassel und Berlin, 1885 .

8. HatscheK, B. Embryonalentwicklung und Knospung der Pedicellina echinata. Zeitschr.f. wiss. Zool., Bd. XXIX. 1877.

9. V. Kennf.L, J. Ueber Ctenodrilus pardalis Clap. Arb. a. d. zool.-zoot. Inst. Wiirzburg, Bd. V, $4 . \quad 1882$.

Io. Ib. Ueber Theilung und Knospung der Thiere. Dorpat, I888.

II. KLeinenberG, N. Die Entstehung des Annelids aus der Larve von Lopadorhynchus. Zeitschr. f. wiss. Zool., Bd. XLIV. 1886.

12. Kükenthal, $W$. Ueber die lymphoiden Zellen der Anneliden. Fen. Zeitschr., Bd. XVIII (XI). 1885 .

13. LANG, A. Ueber den Einfluss der festsitzenden Lebensweise auf die Thiere und über den Ursprung der ungeschlechtlichen Fortpflanzung durch Theilung und Knospung. Jena, I 888. 
14. Meyer, E. Die Abstammung der Anneliden. Biol. Cblatt., Bd. X, Nr. IO. I89o.

15. Milne-Edwards, H. Leçons sur la Physiologie et l'Anatomie comparée de l'Homme et des Animaux, T. VIII. Paris, $186_{3}$.

16. Randolph, H, The Regeneration of the Tail in Lumbriculus. Zool. Anz., Nr. 362 . I 89 I.

77. VAN REES, J. Beiträge zur Kenntnis der inneren Metamorphose von Musca vomitoria. Zool. Fahrb. Abt. f. Anat. u. Ontog., III. 1888.

18. RoHDE, E. Muskulatur der Chætopoden. Zool.Beiträge (A. Schneider), I. 1885 .

19. Seeliger, O. Die Entwickelungsgeschichte der socialen Ascidien. Fen. Zeitschr., Bd. XVIII (XI). I885.

20. Ib. Zur Entwickelungsgeschichte der Pyrosomen. Fen. Zeitschr., Bd. XXIII (XVI). I 889 .

2r. Ib. Die ungeschlechtliche Vermehrung der endoprokten Bryozoen. Zeitschr. f. wiss. Zool., Bd. XLIX. I889.

22. Ib. Bemerkungen zur Knospenentwicklung der Bryozoen. Zeitschr.f. wiss. Zool., Bd. L. I8go.

23. Semper, C. Die Verwandtschaftsbeziehungen der gegliederten Thiere. Arb. a. d. zool.-zoot. Inst. Wiirzburg, III. I877.

24. Weismann, A. Die Continuität des Keimplasmas. I 885 .

25. Wilson, E. B. The Embryology of the Earthworm. Four. Morph., Vol. III. 1889 . 
No. 3.]

EXPLANATION OF PLATES.

REFERENCE LETTERS.

\begin{tabular}{ll|ll} 
al. & Alimentary canal. & $n$. & Neoblast. \\
$c h$. & Neurochord. & n.c. & Neural cord. \\
$c h l$. & Chlorogogue cell. & $n p$. & Nephridium. \\
$c . m$. & Circular muscle. & $n p . c$. & Nephric foundation. \\
$c c$. & Colomic cavity. & $p$. & Peritoneal cell. \\
$d$. & Dissepiment. & $p r$. & Proctodeum. \\
d.v. & Dorsal vessel. & s. & Seta. \\
$e c$. & Ectoderm. & s.gl. & Setigerous gland. \\
$e c . c$. & Ectodermic foundation. & s.f. & Setigerous foundation. \\
$e n$. & Entoderm. & $v . m$. & Ventral mesentery. \\
l.l. & Lateral nerve line foundation. & v.v. & Ventral vessel. \\
$l . m$. & Longitudinal muscle. & v.v.w. & Wall of ventral vessel. \\
$m . l$. & Lateral mesodermic element. & $x$. & Dorsal limit reached by lateral \\
$m . m$. & Median mesodermic element. & & mesodermic elements.
\end{tabular}




\section{EXPLANATION OF PLATE I.}

\section{LUMBriculus variegatus GrUBE.}

Frg. 1. From a transverse section through an adult specimen, showing neoblasts and their relative position. $\times 250$.

FIG. 2. Taken from a preparation made by opening a preserved specimen along the median dorsal line, removing the alimentary canal, blood-vessels and nephridia and flattening out the body wall. The figure extends in the direction of the long axis of the worm, showing the inner surface of the body-wall between the ventral nerve cord and the ventral setæ of the left side. It is from a developing tail that has nearly reached the adult condition, and shows the peritoneal cells of ordinary size and the neoblasts, with intermediate gradations. $\times 600$.

Fig. 3. From a transverse section $\frac{1}{200} \mathrm{~mm}$. thick, the ninth section from the posterior end of a tail one day old, showing neoblasts in the median ventral region. One neoblast is dividing. The proctodeal invagination is, as a rule, at first irregularly from the side. $\times 520$.

Fig. $3^{a}$. A less highly magnified view of the same, showing the whole section.

FIG. 4. From a sagittal section of a tail of one day, showing the region from the alimentary canal through the ventral body-wall. The ectoderm and entoderm are regenerated and a union already effected. The neoblasts are surrounded with a large cell body. The new circular muscles do not appear in the section. The adult nerve cord and muscles end abruptly. $\times 520$.

FrG. 4a. A less highly magnified view giving the whole of the section from which Fig. 4 is taken. $\times 130$.

FIG. 5. From a section of the same series as in Fig. 4, passing through the region on one side of the alimentary canal, showing cell division in what appear to be ordinary peritoneal cells of the dorsal body-wall. Although the tissue of the whole interior of the section is a crowded mass, it is extremely well preserved and the cells in question have every appearance of being normal as to place and condition. $\times 520$.

All figures drawn with camera. 


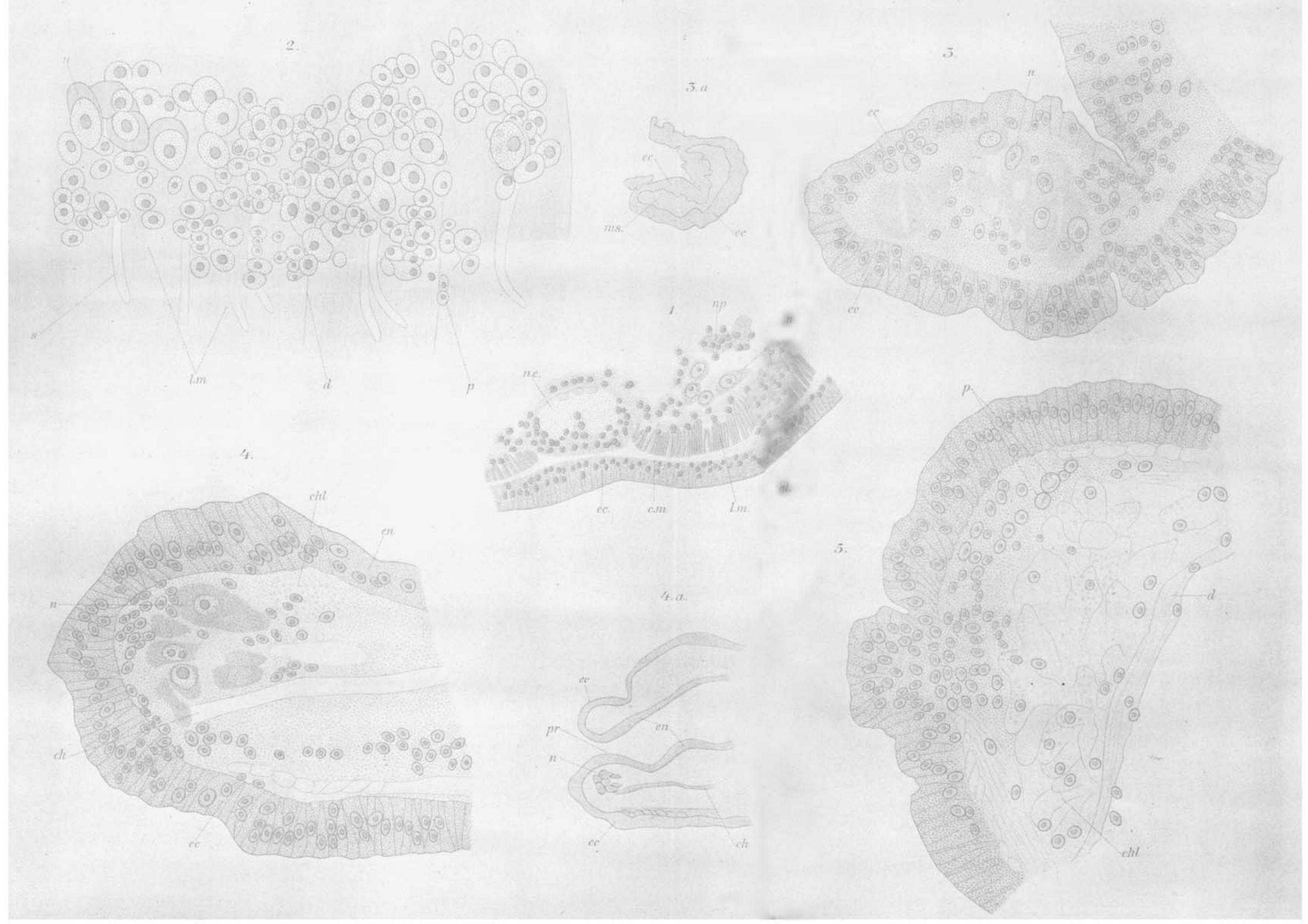




\section{EXPLANATION OF PLATE II.}

\section{LUmbriculus VARIEGATUS Grube.}

FIG. 6. From a transverse section through a developing tail a little more advanced than in Fig. 5, showing the two lateral mesodermic elements and the composite or double median element. The lateral elements have reached dorsally about half of their ultimate height, and contain neoblasts and smaller embryonic cells. The beginnings of the neural and lateral foundations in the ectoderm appear. The paired foundation of the dorsal vessel is visible. $\times 520$.

FIG. 7. Showing a transverse section of a slightly more advanced stage than that figured in 6 . Ventral blood spaces are present. $\times 520$.

FIG. 8. From a transverse section of the same series, the fifteenth section anterior to the one in Fig. 7, each section being $\underset{200}{7} \mathrm{~mm}$. in thickness. Irregular spaces appear in the mesoderm which has reached its extreme dorso-lateral limit $(x)$. The foundations in the ectoderm are very clearly marked: two ventral foundations, one on each side of the median ventral line, which later unite to form the ventral nerve cord; on each side of these are four foundations of which the upper on each side forms the dorsal setigerous glands, and those next ventral to it the lateral nerve line; the two on each side between the lateral line and the ventral neural foundations correspond to the setigerous and nephric foundations of Lumbricus. $\times 520$.

FIg. 9. From the same series four sections anterior to Fig. 8, showing the colomic spaces in the new mesodermic tissue: one in each of the lateral elements and one in each median element. The last-mentioned spaces later unite to form the coelomic space between the ventral nerve cord and the ventral blood vessel. $\times 520$.

All the figures drawn with the camera. 


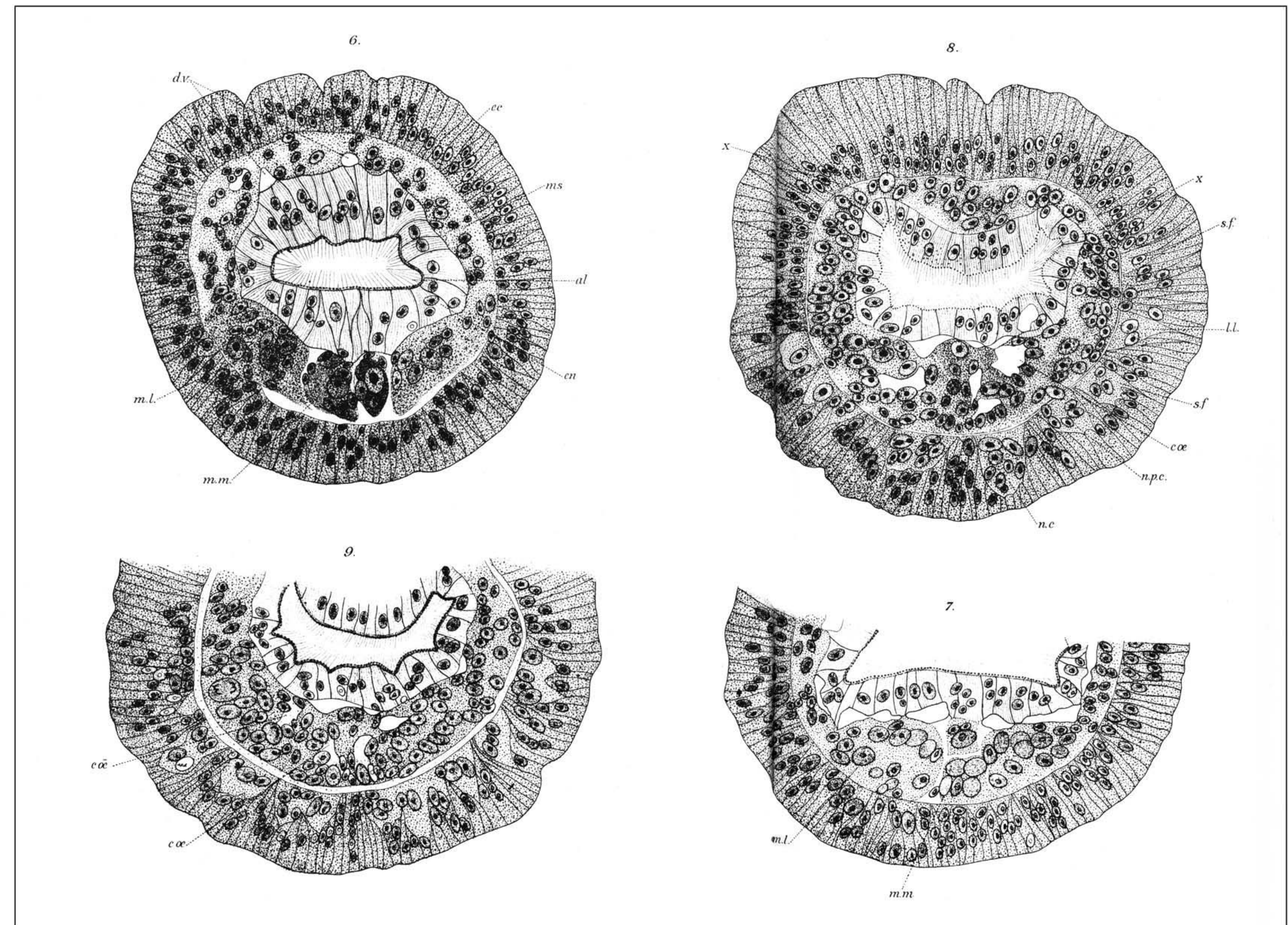




\section{EXPLANATION OF PLATE III.}

\section{LUmbriculus VARIEgatus Grube.}

FIG. I0. From a transverse section through a more advanced stage than in Fig. 9. The median colomic spaces have united and more cavities appear in the lateral mesodermic elements. The neural foundations have united in the median line and nerve fibres have developed. $\times 490$.

FIG. 10a. A less highly magnified view of the section shown in Fig. 10. $\times 250$.

FiG. II. From a section of the same series as in Figs. 7,8 , 9, sixty-five sections anterior to the one figured in 9. The dorsal wall of the median cœlomic cavity has grown down into the cavity and the sides of the loop thus formed have united above, making a tube which is the ventral longitudinal blood vessel. The neural cord with cells and fibres is now well developed. $\times 600$.

Fig. I2. From a transverse section of a stage more advanced than that in Fig. $\mathbf{n}$. The tissues and the colomic cavity have nearly reached the adult condition. A neoblast in characteristic position shows the nucleus and cell body. $\times 600$.

FIG. I2a. From the section next to that in Fig. 12, showing the nucleolus of the neoblast in Fig. 12, and the connection of the setigerous gland with the ectoderm. $\times 520$.

All the figures were drawn with camera. 


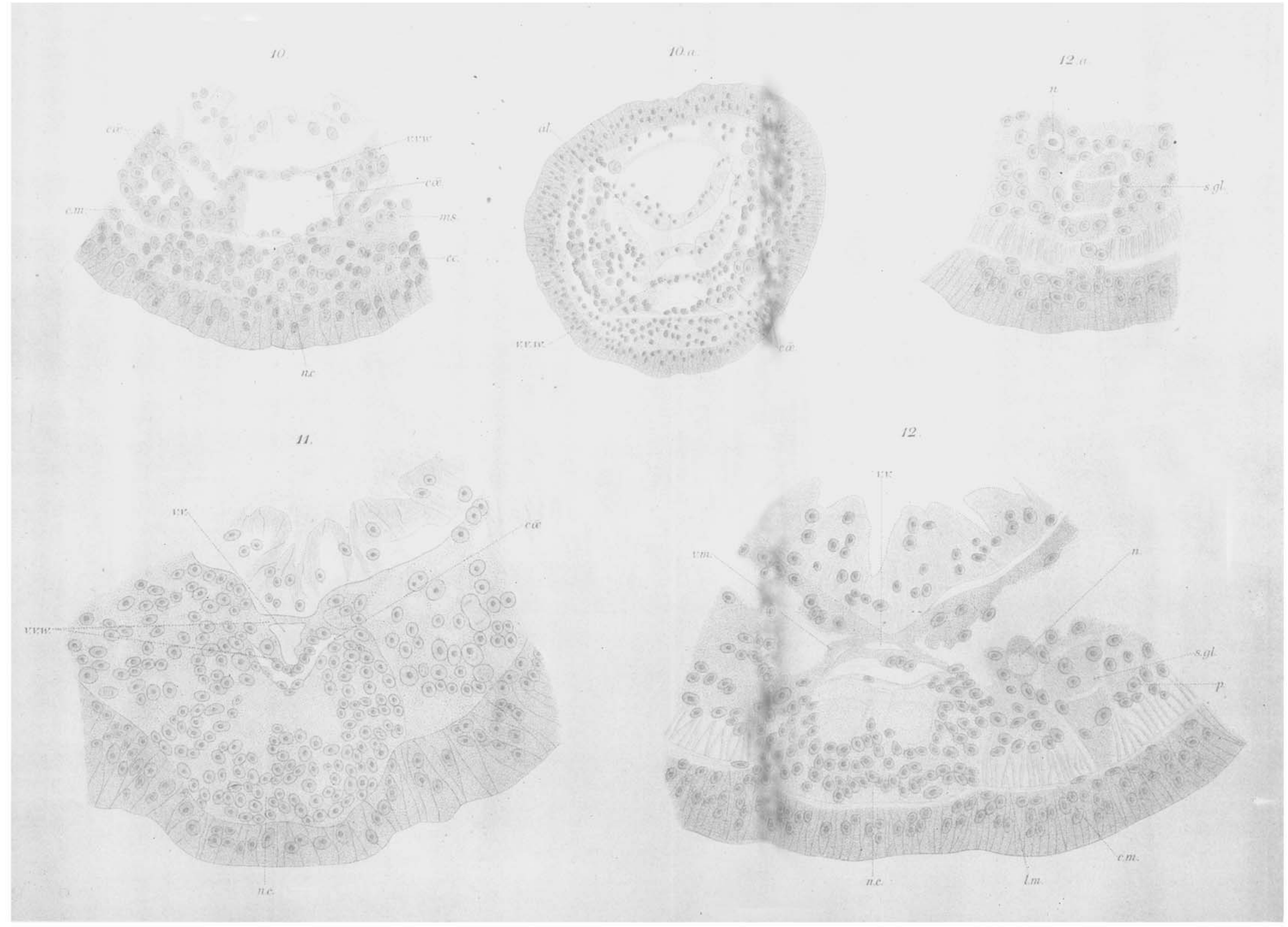




\section{EXPLANATION OF PLATE IV.}

(Figs. I3, 14, 15, I7, 18, 19, 20. Lustbriculus variegatus Grube. Figs, 16, 16a. Lumbricus olidus Hoffm. (Allolobophora fatida Sav.).)

Fig. I3. From a sagittal section of a slightly advanced stage, showing the connection of the developing neural cord with the ectoderm. $\times 300$.

FIG. I4. From a longitudinal vertical section of a more advanced specimen, showing the fusion of the nephric foundation with the mesoderm. The plane of the section is slightly oblique, passing at the right of the figure through the longitudinal muscles, and at the middle and left through the centre of the foundation. $\times 5^{20}$.

Fig. 15. From the same series as in Figs. 7, 8, 9, and 11 , the seventh section anterior to the one figured in 9, showing the double origin of the dorsal vessel, and being an advance upon the condition shown in Fig. $6 . \times 520$.

FIG. I6. From a transverse section through the regenerating tail of Lumbricus olidus, Hoffm. (Allolobophora fotida, Sav.), showing mesodermic elements, lateral and composite median, corresponding to those in Lumbriculus and consisting of embryonic tissue which stains more deeply, and is therefore easily distinguishable from the adult tissue with which it is surrounded. $\times 270$.

FIG. $16 a$. The whole section of which Fig. 16 shows a more highly magnified part. Immediately ventral to the new mesodermic tissue is a mass of deeply stained cells which are in connection anteriorly with the ventral nerve cord, and posteriorly with the new ectoderm ventral to the proctodeal invagination. The figure shows the relatively small area occupied at first by the regenerated tissue and its position surrounded by the adult tissues. The outlines were drawn with the camera and the details are half schematic. $\times 60$.

Fig. 17. From a longitudinal vertical section of an early stage, stained with borax carmine, and afterwards with picric acid dissolved in $7^{\circ}$ per cent alcohol, showing the beginning of the formation of the circular muscles. The figure is from a section much thinner than the average (which is $\frac{1}{20} \mathrm{~mm}$.), which makes it possible to see the faint lines along which the fibrillæ later separate. The dark-pointed tips represent the amount of elongation of the fibre in its long axis (around the body-wall of the worm) on each side of the nucleus. $\times 45^{\circ}$.

Fig. 18. Showing a longitudinal vertical section from a regenerated tail about two days old. The fibrillæ have begun to separate from one another and from that part of the peripheral layer of the fibre in contact with the ectoderm. $\times 450$.

FIG. 19. From a longitudinal vertical section of a specimen older than in Fig. I 8 , showing a structure similar but more advanced. This is practically the adult condition which is generally obscured by the pressure of the longitudinal muscles. $\times 450$.

FIG, 20. From a longitudinal vertical section of a regenerated tail of four days' growth. The section shows the ectodermic foundation lying still in the ectoderm, and at the same time the circular muscles already formed both in the region of the ectodermic foundation and far posterior to it where the ectoderm is still undifferentiated. $\times$ Ioo.

All the figures, except I $6 a$, drawn with camera. 


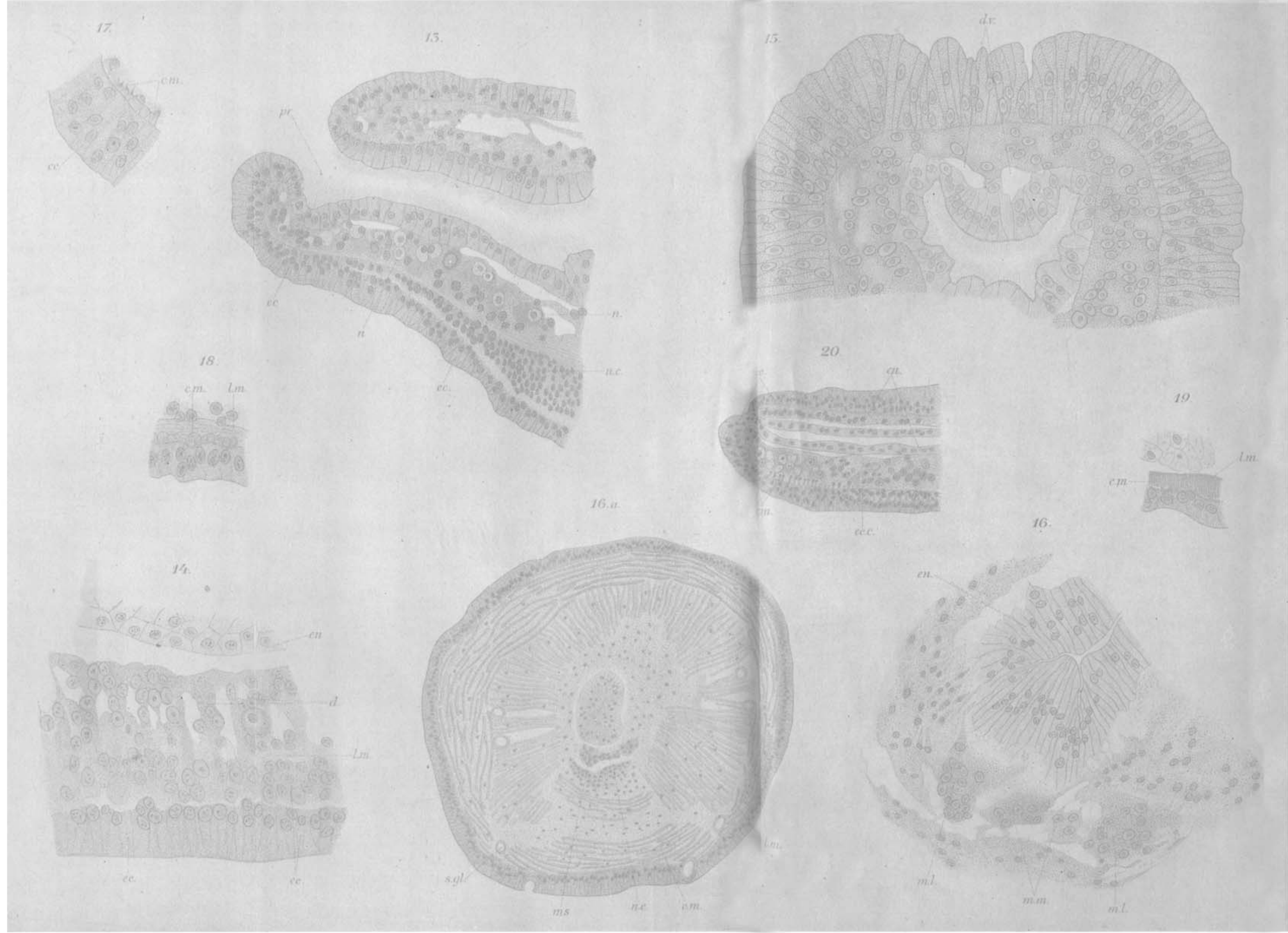

